\title{
The Dynamic Change of Pore Structure for the Low-Rank Coal with Various Pretreatment Temperatures: A Case Study from Southwestern Ordos Basin
}

\author{
Teng Li $\mathbb{D}^{1,2,3}$ \\ ${ }^{1}$ College of Petroleum Engineering, Xi'an Shiyou University, Xi'an, Shaanxi 710065, China \\ ${ }^{2}$ Shandong Key Laboratory of Depositional Mineralization \& Sedimentary Mineral, Shandong University of Science and Technology, \\ Qingdao, Shandong 266590, China \\ ${ }^{3}$ Shaanxi Key Laboratory of Advanced Stimulation Technology for Oil \& Gas Reservoirs, Xi'an Shiyou University, Xi'an, \\ Shaanxi 710065, China \\ Correspondence should be addressed to Teng Li; liteng2052@163.com
}

Received 7 March 2020; Revised 16 June 2020; Accepted 18 June 2020; Published 1 July 2020

Academic Editor: Andrea Brogi

Copyright (c) 2020 Teng Li. This is an open access article distributed under the Creative Commons Attribution License, which permits unrestricted use, distribution, and reproduction in any medium, provided the original work is properly cited.

\begin{abstract}
The pore characteristics of the low-rank coal are different from medium- and high-rank coals. The low-temperature $\mathrm{N}_{2}$ adsorption (LP- $\mathrm{N}_{2} \mathrm{~A}$ ) measurements with a single low-rank coal were launched, and the dynamic change of pore structures under various pretreatment temperatures from $120^{\circ} \mathrm{C}$ to $300^{\circ} \mathrm{C}$ was studied. The isothermal curves of the DFS coal sample feature IV type, the hysteresis loops convert from $\mathrm{H}_{4}$ type to $\mathrm{H}_{2}$ type, and the hysteresis loops tend to be closed with the increased pretreatment temperatures. The mesopores are dominant in the DFS coal. The dynamic of pore volume (PV) and pore specific surface area (SSA) features the three-step-style change with the cut-off temperature points at $150^{\circ} \mathrm{C}$ and $240^{\circ} \mathrm{C}$, and this has a relationship with the loss of the moisture and volatiles in the DFS coal sample. The pores with an aperture below $10 \mathrm{~nm}$ are the dominant mesopores in the DFS coal, and the mesopore volume features bimodal pattern distribution with a higher left peak of approximately $1.7 \mathrm{~nm}$ and a lower right peak of approximately $3-5 \mathrm{~nm}$, and the right peak continuously right shift with the increase pretreatment temperatures. The total mesopore volume decreases with the upgrading temperatures, while the ratio of pores greater than $5 \mathrm{~nm}$ increases. Finally, the mesopore evolution model with the increased pretreatment temperatures was summarized.
\end{abstract}

\section{Introduction}

The low-rank coal generally has a maximum vitrinite reflectance of $0.65 \%\left(R_{\mathrm{o}, \max }<0.65 \%\right)$, with the typical characteristics of high content of moisture and volatiles [1-4]. The low-rank coalbed methane has been commercially developed in America, Canada, and Australia, which also accelerates the research on the low-rank coalbed methane in China [5-7]. As an essential evolution parameter, the pore structure plays an important role on low-rank coal reservoir, and it has attracted more attention in recent years [8-12].

The coalification, macerals, ash yield, moisture, and the content of vitrinite feature significantly influence on the pore structure of the low-rank coal [6, 12-14]. Nugroho et al. [15] reported that the mesopores $(2-50 \mathrm{~nm})$ and macropores $(>50 \mathrm{~nm})$ are dominant in the low-rank coal, especially that for the mesopores, and the pore specific surface area (SSA) is mainly contributed by the mesopores ([16]). Besides, the pore diameters in the low-rank coal are commonly below $10 \mathrm{~nm}$ [17], and the pores with the aperture less than $2 \mathrm{~nm}$ are open and semiopen; the typical pore structure determines it favors the adsorption rather than the seepage of the methane $[1,13]$. However, it should be noted that the low-rank coal from Ordos Basin shows a high proportion of the mesopores ranging from $10 \mathrm{~nm}$ to $50 \mathrm{~nm}$ [6]. The plant tissue pores in the low-rank coal are developmental, and these pores are mainly macropores; the macropore volume reaches the minimum when the $R_{\mathrm{o}, \max }=0.5 \%$ [2]. With the increased 
coalification of the low-rank coal, the rapid decrease of the quantity of the plant tissue pores also contributes to the decreased pore volume [18]. Besides, the clay minerals would also damage the plant tissue pores $[11,19]$.

When the $R_{o, \max }$ reaches $0.6 \%$, the low-rank coal would also produce certain amounts of pyrolysis oil, and the pyrolysis oil is the condensation of the pyrolysis gas from the lowrank coal [20]. Due to the thermodynamic action, the surface of the micropore becomes coarse $[21,22]$, the ratio of the macropores increases [23], and the proportions of the pores in various range tend to balance. Once the thermal temperature exceeds $450^{\circ} \mathrm{C}$, there would be a significant change of the coal molecule structure for the low-rank coal [24].

The low-rank coal also contains high moisture content. During the upgrading temperature of the coal thermal evolution, the loss of the moisture has a significant influence on pore structure, which will finally lead to the dynamic change of the pore structure of the low-rank coal $[25,26]$. The pores and intermicellar capillaries of the low-rank coal contain a thickness of 4 to 5 water molecules [4]. These water can be generally divided into adsorbed water, free water, and chemically bonded water [27], and the water can also be classified finely into interparticle water, capillary water, adhesion water, surface adsorption water, and interior adsorption water [24, 28-31]. When the test temperature exceeds the boiling point of the water, the content of water in the lowrank coal would decrease ([32]; [24]). The interparticle water and adhesion water commonly exist in the macropores, and these types of water could be evaporated when the test temperatures range from $100^{\circ} \mathrm{C}$ to $250^{\circ} \mathrm{C}$ [31]. Although there would be a certain pore collapse at these temperatures, it is weak [33]. When the test temperature exceeds $200^{\circ} \mathrm{C}$, the PV and SSA of the mesopores would decrease [34]. When the water that exists in the pore with the aperture of $5 \mathrm{~nm}$ tends to decrease, the shrink caused by the emptying would lead to the collapse of the pores $[25,33]$, especially when the pore diameter corresponds to two water molecular layers ([35]); there would be a significant decrease of the pore volume. With the increased temperature, there would be irreversibility shrinkage of the transition and macropore (mainly with a range from $5 \mathrm{~nm}$ to $120 \mathrm{~nm}$ ), leading to the continuous decrease of the pore volume [33]. During these processes, the SSA of pores with an aperture of $2 \mathrm{~nm}$ to $18 \mathrm{~nm}$ present a continuous decrease [36]. The loss of the water in the lowrank coal leads to the collapse of the pore [37].

Due to the typical property characteristics of high moisture and volatiles for the low-rank coal, the evaporation of moisture and decomposition of the volatiles under high temperatures from the coal would change the pore structure of the low-rank coal. As known, the low-temperature $\mathrm{N}_{2}$ adsorption (LP- $\left.\mathrm{N}_{2} \mathrm{~A}\right)$ measurements are dominantly utilized to acquire the pore structure of the porous medium under certain temperatures. With various temperatures, different pore structure characteristics of the low-rank coal could be acquired, which may lead to an inaccurate evaluation of the low-rank coal. Although the dynamic change of the low-rank coal pore structure, PV and SSA, with the increased coalification has been studied in detail, these researches mainly launched with
TABLE 1: The $R_{\mathrm{o}, \max }$ and proximate analysis of DFS coal sample.

\begin{tabular}{lcccc}
\hline \multirow{2}{*}{ Sample } & \multirow{2}{*}{$R_{\mathrm{o}, \max }(\%)$} & \multicolumn{4}{c}{ Proximate analysis (\%) } \\
& & $M_{\mathrm{ad}}$ & $A_{\mathrm{d}}$ & $V_{\mathrm{daf}}$ \\
\hline DFS & 0.62 & 5.07 & 17.55 & 38.18 \\
\hline
\end{tabular}

the massive series coal samples, and there is seldom attention on the dynamic change of pore structure for the single lowrank coal sample under various pretreatment temperatures. In this study, a low-rank coal sample was collected from the southwestern of the Ordos Basin, with the artificial coal grain sizes of 60-80 mesh; this single coal sample was primarily dealt with various pretreatment temperatures ranging from $120^{\circ} \mathrm{C}$ to $300^{\circ} \mathrm{C}$ with an interval of $30^{\circ} \mathrm{C}$; then, the $\mathrm{LP}-\mathrm{N}_{2} \mathrm{~A}$ measurements of this coal sample were carried out to investigate the dynamic change of the pore structure.

\section{Samples and Measurements}

2.1. Samples. The low-rank coal sample was collected from the Dafosi (DFS) coal mine in Binchang mining area, southwestern Ordos Basin. The target stratum is the middle Jurassic Yan'an Formation, which is the coal-bearing stratum in the mining area. Yan'an Formation is a plain river terrestrial deposit with 6 coal seams, $3^{-1} \#, 3^{-2} \#, 4^{1-1} \#, 4^{1-2} \#, 4^{1} \#$, and $4 \#$ coal seams from the upper to the lower, respectively, and the $4 \#$ coal seam is the main mining coal seam. It is easy for the low-rank coal to lose the water under room temperature; then, the fresh coal sample was packaged with the sealed valve bag immediately once it is collected from the working face, and the coal samples were sent to the laboratory to launch the measurements rapidly.

\subsection{Preparation and the Measurements of the Samples}

2.2.1. Properties of the Low-Rank Coal. To avoid the probable oxidation on the low-rank coal, the surface of the bulk coal was scraped before it is ground to the normative coal particles for the basic property measurements and the LP-N ${ }_{2} \mathrm{~A}$ measurements. Subsequently, the coal was pulverized with the grain sizes from 60 mesh to 80 mesh using standard laboratory test sieves. The basic properties were measured to acknowledge coal samples, including the maximum reflectance of the vitrinite and the proximate analysis. The maximum reflectance of the vitrinite was measured according to the Chinese national standard (GB/T 6948-2008), and the Chinese national standard of GB/T 212-2008 was used to measure the proximate analysis of the coal samples.

2.2.2. The LP- $\mathrm{N}_{2} A$ Measurements under Various Pretreatment Temperatures. Before the LP- $\mathrm{N}_{2} \mathrm{~A}$ measurements, the sample tube was firstly dried under $150^{\circ} \mathrm{C}$ with the Micromeritics VacPrep 061 Sample Degas System. The Micromeritics VacPrep 061 Sample Degas System can provide a wide temperature range from $20^{\circ} \mathrm{C}$ to $330^{\circ} \mathrm{C}$ with a precision accuracy of $\pm 0.1^{\circ} \mathrm{C}$, which can accurately control the pretreatment temperatures. The main purpose of the pretreatment of the sample tube is to wipe the moisture on the surface of the tube. After drying $3 \mathrm{~h}$, the sample tube would be cooled and balanced. 


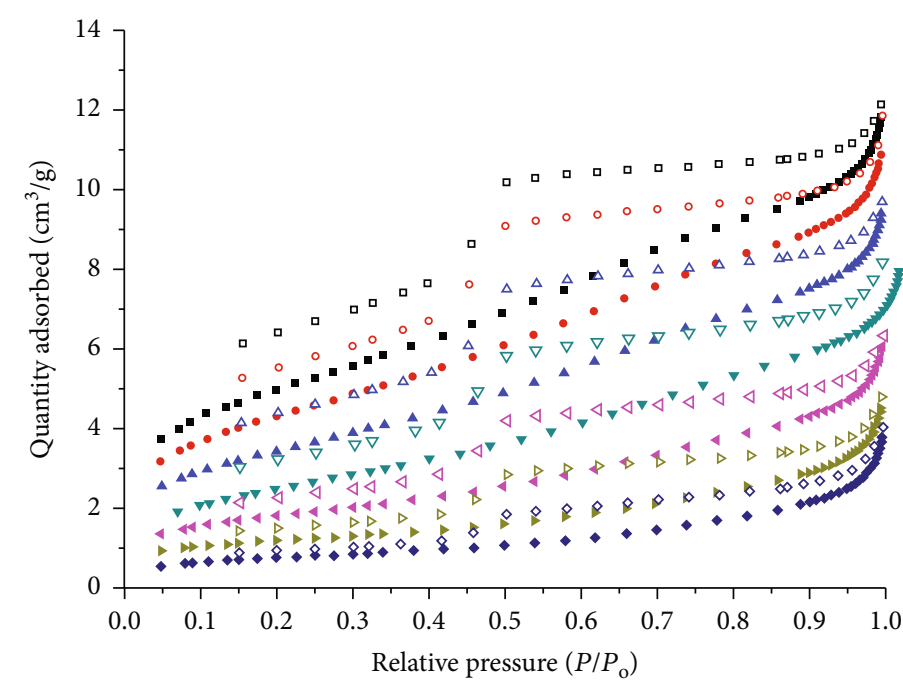

- Adsorption curve at $120^{\circ} \mathrm{C}$ a Desorption curve at $120^{\circ} \mathrm{C}$

- Adsorption curve at $150^{\circ} \mathrm{C} \quad$ o Desorption curve at $150^{\circ} \mathrm{C}$

$\Delta$ Adsorption curve at $180^{\circ} \mathrm{C} \Delta$ Desorption curve at $180^{\circ} \mathrm{C}$

v Adsorption curve at $210^{\circ} \mathrm{C} \quad \nabla$ Desorption curve at $210^{\circ} \mathrm{C}$

4 Adsorption curve at $240^{\circ} \mathrm{C} \triangleleft$ Desorption curve at $240^{\circ} \mathrm{C}$

- Adsorption curve at $270^{\circ} \mathrm{C} \triangleright$ Desorption curve at $270^{\circ} \mathrm{C}$

- Adsorption curve at $300^{\circ} \mathrm{C} \diamond$ Desorption curve at $300^{\circ} \mathrm{C}$

FIgURE 1: The isothermal adsorption and desorption curves of coal under various pretreatment temperatures.

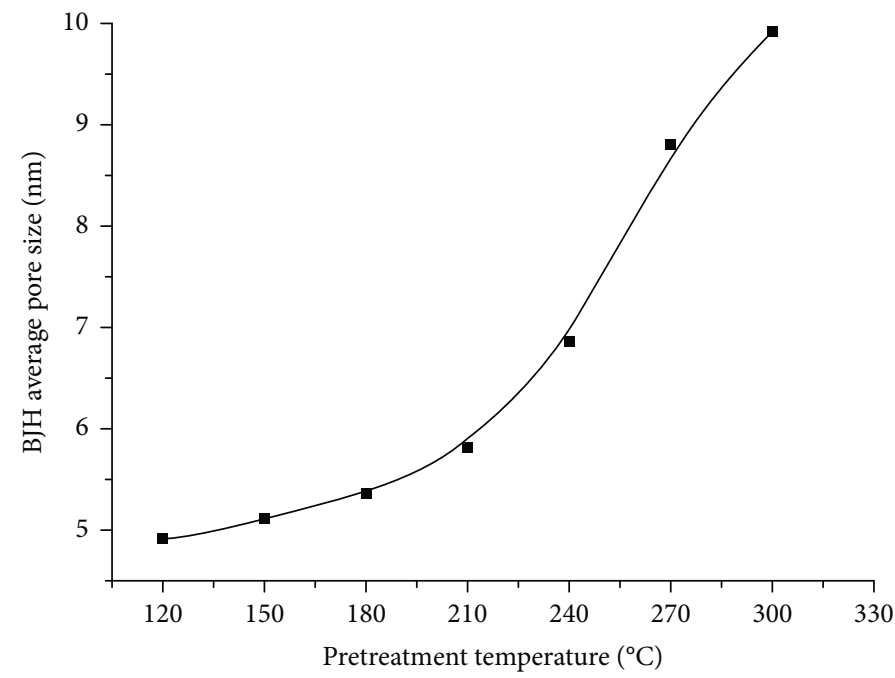

FIgURE 2: The dynamic change of the average pore sizes under various pretreatment temperatures.

To acquire the pore structure of the low-rank coal under various pretreatment temperatures, the moderate fine coal sample would be added into the sample tube, and the sample would be dried under $120^{\circ} \mathrm{C}$ firstly. In order to ensure the same vacuum condition for the following various pretreatment temperatures, the vacuum degree of 0.05 mbar was utilized to identify the completed vacuum drying measurement. After the drying, the mass of the sample and the sample tube would be balanced again to acquire the mass of the coal sample. Finally, the LP- $\mathrm{N}_{2} \mathrm{~A}$ measurement would be launched under the $-196^{\circ} \mathrm{C}(77.15 \mathrm{~K})$ with a maximum relative pressure at approximately 1 . When the LP- $\mathrm{N}_{2} \mathrm{~A}$ measurement under the pretreatment temperature of $120^{\circ} \mathrm{C}$ was completed, the coal sample would not be discarded, and it would be dried again under various pretreatment temperatures, $150^{\circ} \mathrm{C}, 180^{\circ} \mathrm{C}$, $210^{\circ} \mathrm{C}, 240^{\circ} \mathrm{C}, 270^{\circ} \mathrm{C}$, and $300^{\circ} \mathrm{C}$, respectively. With the same measurement procedures, the LP- $\mathrm{N}_{2} \mathrm{~A}$ measurements under various pretreatment temperatures could be carried out.

During the whole measurements, the room temperature was controlled to $20^{\circ} \mathrm{C}$. The Barrett-Joiner-Halenda (BJH) 


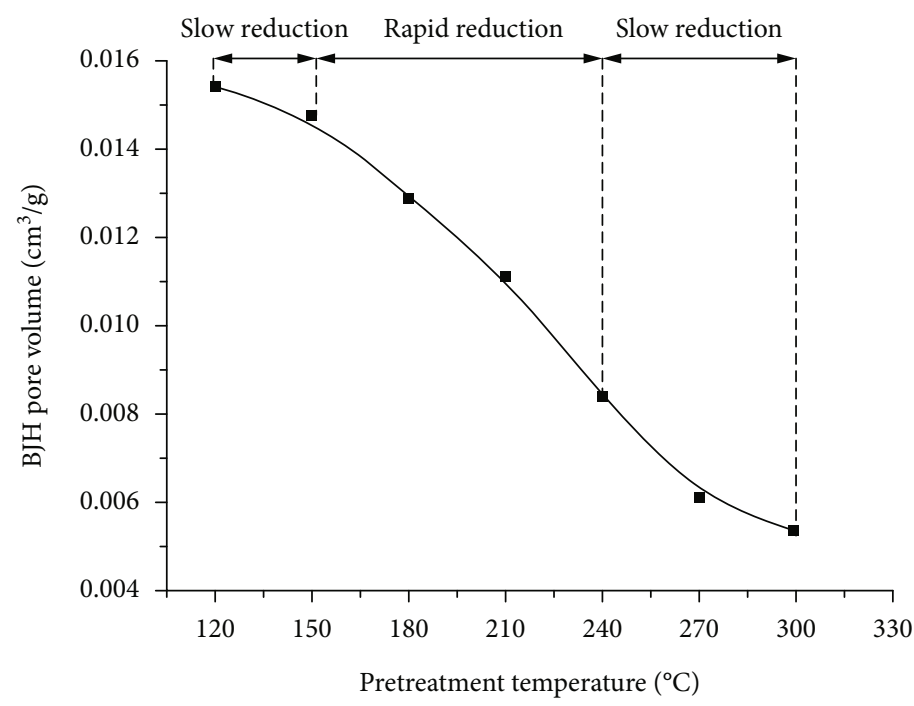

FIGURE 3: The dynamic change of total PV under various pretreatment temperatures.

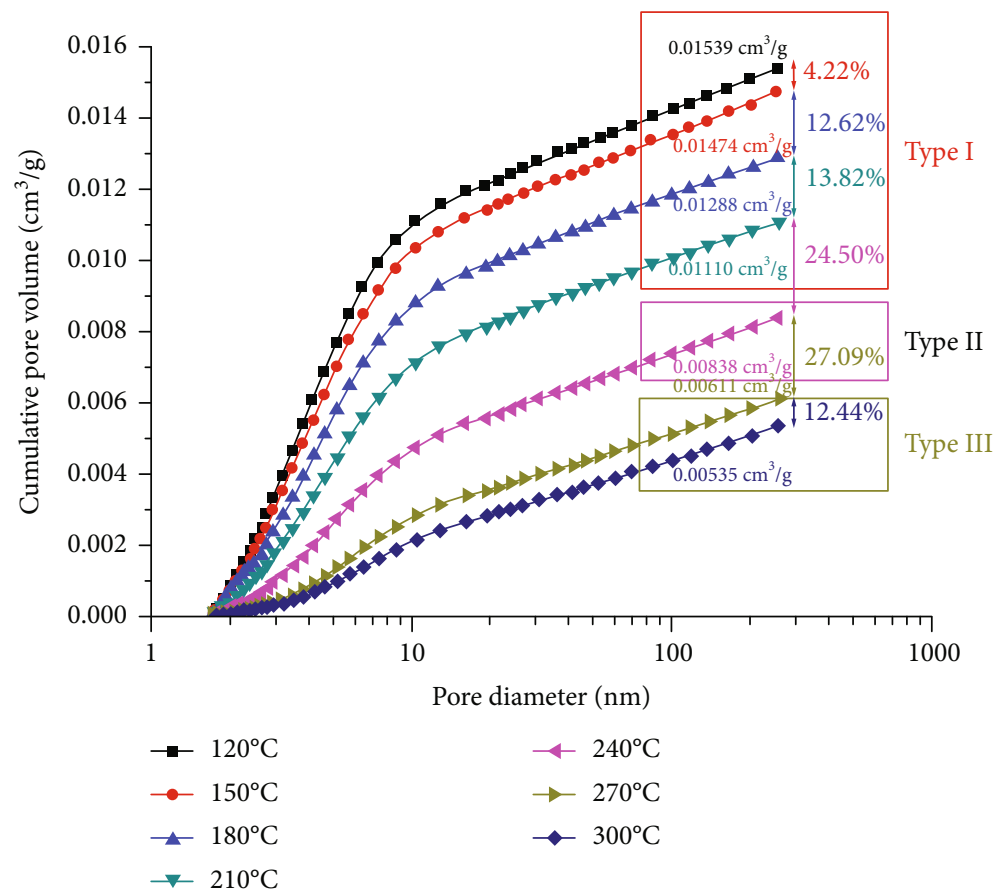

FIgURE 4: The cumulative PV under various pretreatment temperatures.

method was used to calculate the PV and the pore size distribution (PSD), and the Brunauer-Emmett-Teller (BET) method was utilized to acquire the pore SSA.

\section{Results and Discussion}

3.1. The Properties of the Coal Sample. As shown in Table 1, the $R_{\mathrm{o} \text {,max }}$ of the DFS coal sample is $0.62 \%$, which is the long-flame coal. The moisture content on the air-dry basis of the coal sample is $5.07 \%$, the ash yield on a dry basis is $17.55 \%$, and the volatile matter yield on a dry, ash-free basis is $38.18 \%$. It can be seen that the moisture in the DFS coal sample is low, whereas that for the volatiles are high.

3.2. The $L P-N_{2} A$ Curves. The IUPAC pore classification method was utilized to distinguish the pores in the coal, micropore $(<2 \mathrm{~nm})$, mesopore $(2-50 \mathrm{~nm})$, and macropore $(>50 \mathrm{~nm})$, respectively. The previous studies have shown that the pores in low-rank coal are mainly meso- and macropores ([15]; [16]; [1, 17]). Then, the dynamic changes of the mesoand macropores were mainly focused. According to the recommended IUPAC classification method, there are six 


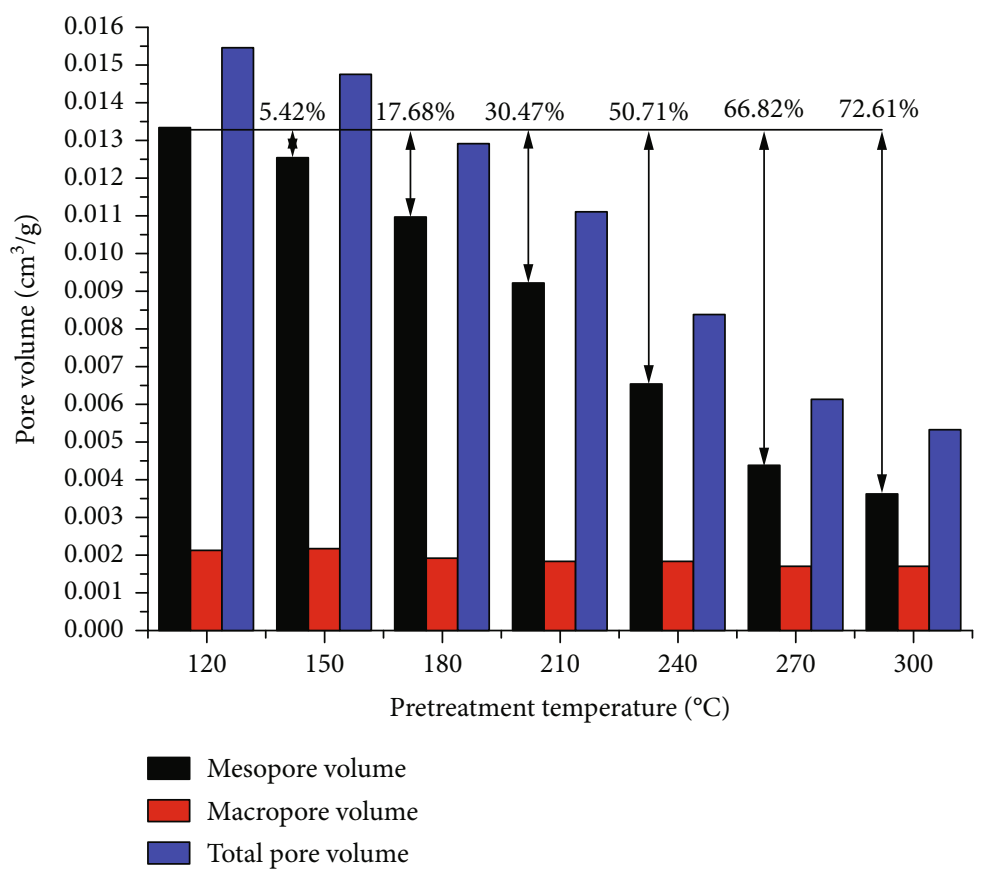

FIGURE 5: The dynamic change of meso- and macropore volumes under various pretreatment temperatures.

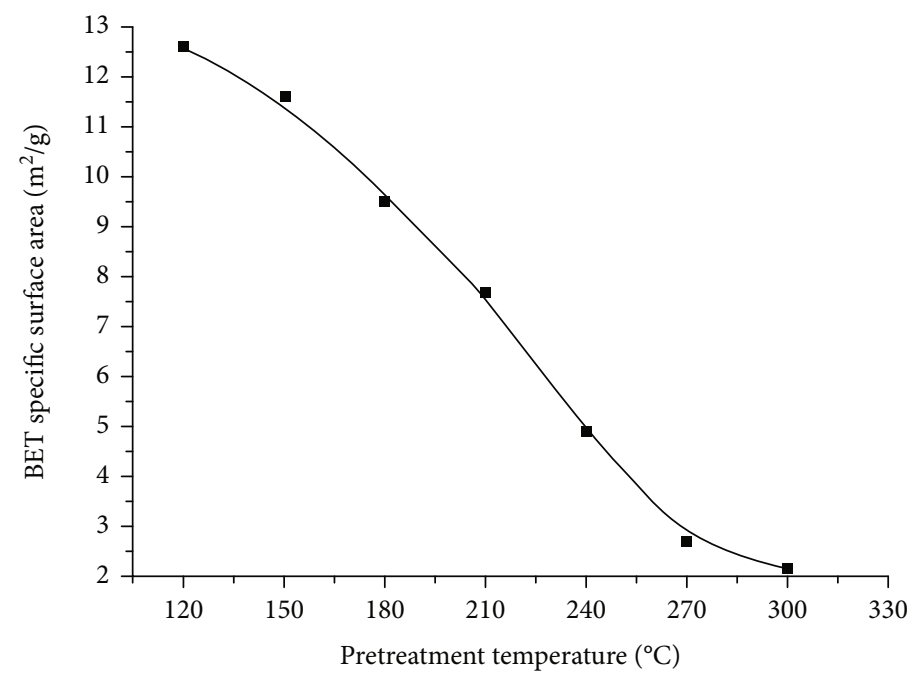

FIGURE 6: The dynamic change of total pore specific surface area under various pretreatment temperatures.

different adsorption curves for the porous materials, and it can form four types of hysteresis loops [38].

With the minimum pretreatment temperature, the lowrank coal presents the maximum $\mathrm{N}_{2}$ adsorption quantity, and the $\mathrm{N}_{2}$ adsorption quantities decrease with the increased pretreatment temperatures (Figure 1). For the adsorption branch, the $\mathrm{N}_{2}$ adsorption quantity increases stably when the relative pressure is below 0.9 . When the relative pressure exceeds 0.95 , there is a sharp increase in the $\mathrm{N}_{2}$ adsorption quantity. The $\mathrm{N}_{2}$ adsorption rates are quite quicker when the pretreatment temperature of the coal is below $240^{\circ} \mathrm{C}$. The desorption branch of the coal presents step-style change. The desorption branch shows a sharp decrease with the relative pressure reduces to 0.9 ; then, it features slowly with the relative pressure ranging from 0.5 to 0.9 . There is an obvious decrease when the relative pressure ranges from 0.4 to 0.5 . Subsequently, the desorption branch features a slow decrease under the lower relative pressure. Under the various pretreatment temperatures, the shapes and sizes of the hysteresis loops are various, indicating the dynamic change of the shapes and connectivity of the pores. Figure 1 shows that the isothermal curves of the low-rank coal under various pretreatment temperatures are IV type, and the hysteresis loops convert from $\mathrm{H}_{4}$ type to $\mathrm{H}_{2}$ type with the increased pretreatment temperatures. 


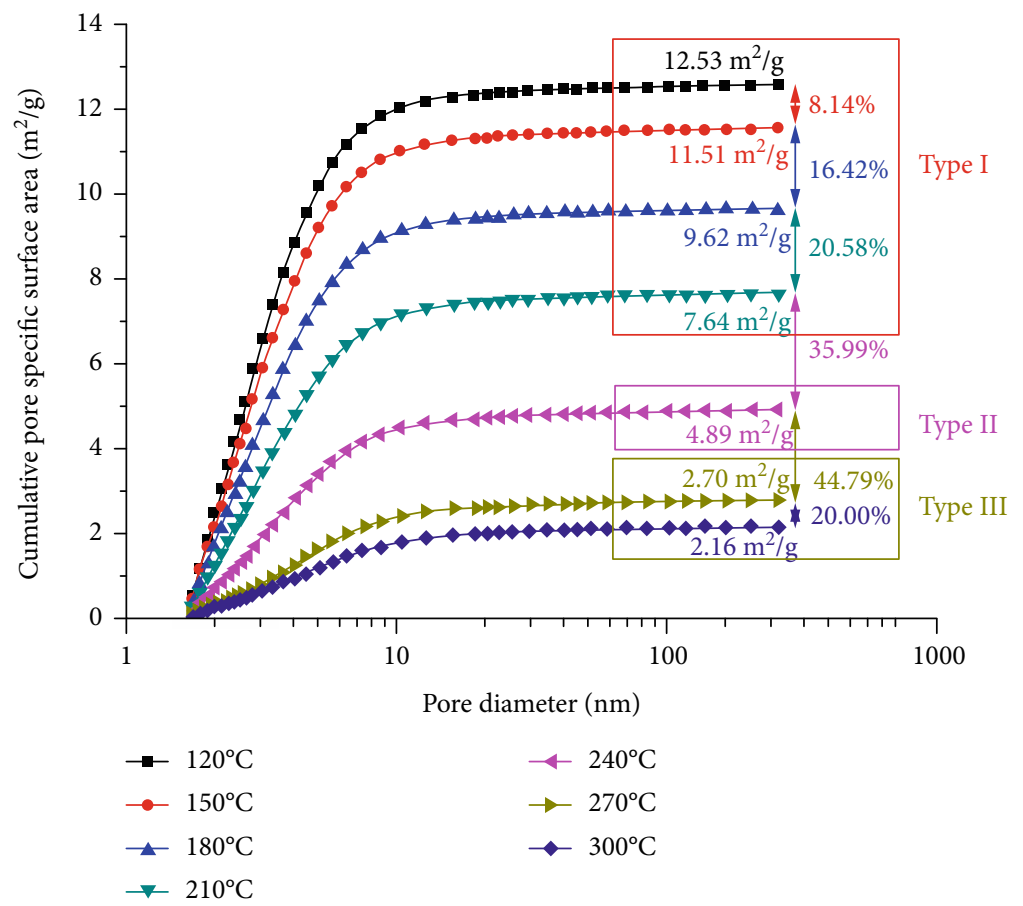

FiguRE 7: The cumulative pore specific surface area under various treatment temperatures.

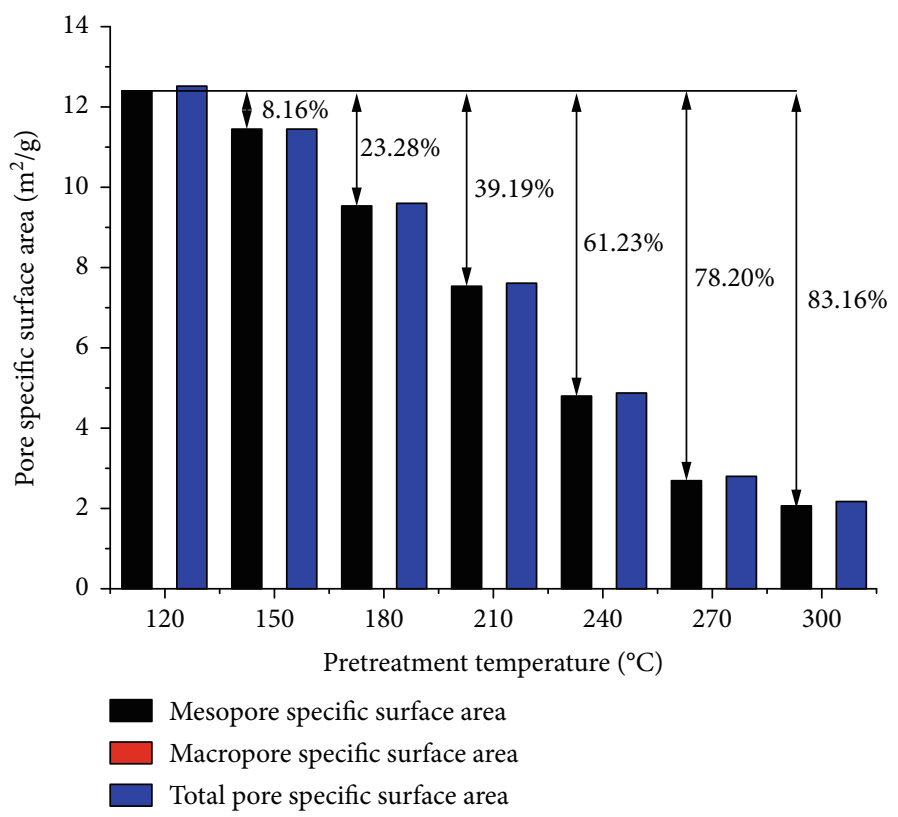

Figure 8: The dynamic change of meso- and macropore specific surface area under various pretreatment temperatures.

\subsection{The PV and SSA of the Coal under Various Pretreatment Temperatures}

3.3.1. The Change of $P V$. With the increased pretreatment temperatures of the coal, the average pore diameter of the coal increases from $4.92 \mathrm{~nm}$ to $9.92 \mathrm{~nm}$ (Figure 2). The total PV decreases from $0.01539 \mathrm{~cm}^{3} / \mathrm{g}$ to $0.00535 \mathrm{~cm}^{3} / \mathrm{g}$ with the increased pretreatment temperatures (Figure 3), and there is almost a decrease of $65.24 \%$. The decrease of the total PV presents as a three-step-style. Below the $150^{\circ} \mathrm{C}$, there is a slow decrease of the total PV from $0.01539 \mathrm{~cm}^{3} / \mathrm{g}$ to $0.01474 \mathrm{~cm}^{3} / \mathrm{g}$. With the continuous increase of the pretreatment temperatures, the total PV decreases sharply, and the total PV is only $0.00838 \mathrm{~cm}^{3} / \mathrm{g}$ when the pretreatment temperature reaches $240^{\circ} \mathrm{C}$. Subsequently, the decrease of the total PV of the coal slows down again, and it decreases to $0.00535 \mathrm{~cm}^{3} / \mathrm{g}$ when the temperature is $300^{\circ} \mathrm{C}$ (Figure 4 ). 


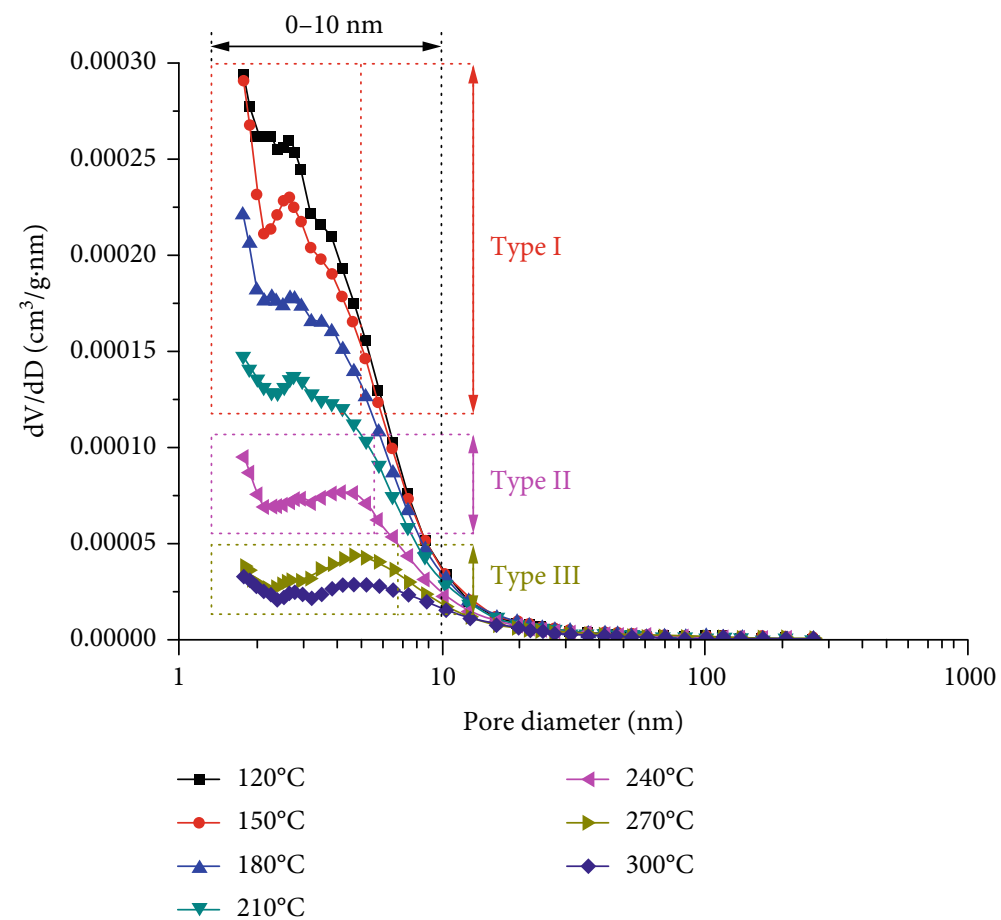

FIGURE 9: The incremental pore volume of coal under various pretreatment temperatures.

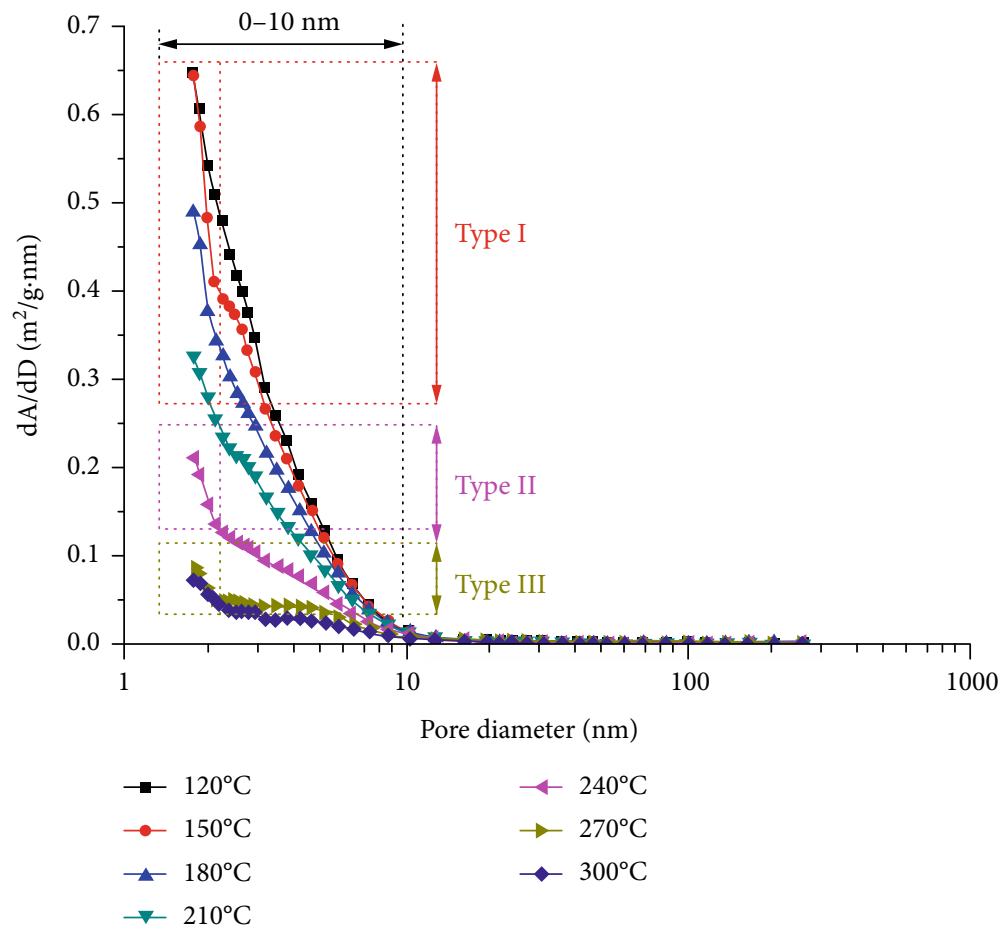

Figure 10: The incremental pore specific surface area of coal under various pretreatment temperatures.

Figure 5 shows that the mesopores are dominant in the low-rank coal. Under the pretreatment temperature of $120^{\circ} \mathrm{C}$, the meso- and macropore volumes are $0.01329 \mathrm{~cm}^{3} / \mathrm{g}$ and $0.00211 \mathrm{~cm}^{3} / \mathrm{g}$, respectively. When the pretreatment temperature rises to $300^{\circ} \mathrm{C}$, the meso- and macropore volumes decrease to $0.00364 \mathrm{~cm}^{3} / \mathrm{g}$ and $0.00171 \mathrm{~cm}^{3} / \mathrm{g}$, respectively. It can be found that the macropore volume decreases weakly with the increased temperatures, while there is a significant decrease of the mesopore volume. The reduction features between the mesopore volume and the total PV are homologous, indicating the total PV is determined mainly by the mesopore in the DFS coal (Figure 5). The total PV is mainly 


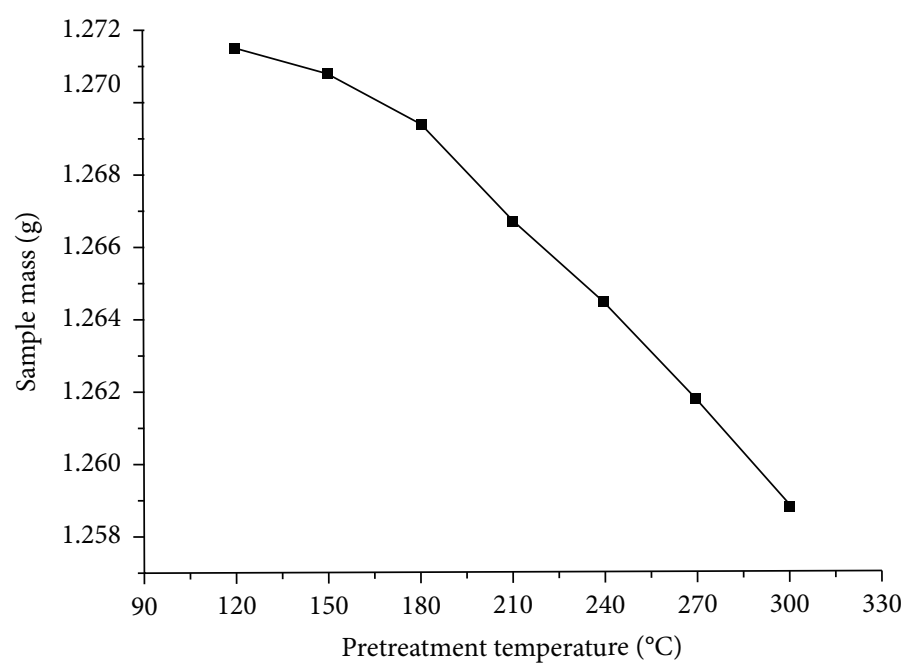

FIGURE 11: The dynamic change of mass under various pretreatment temperatures.
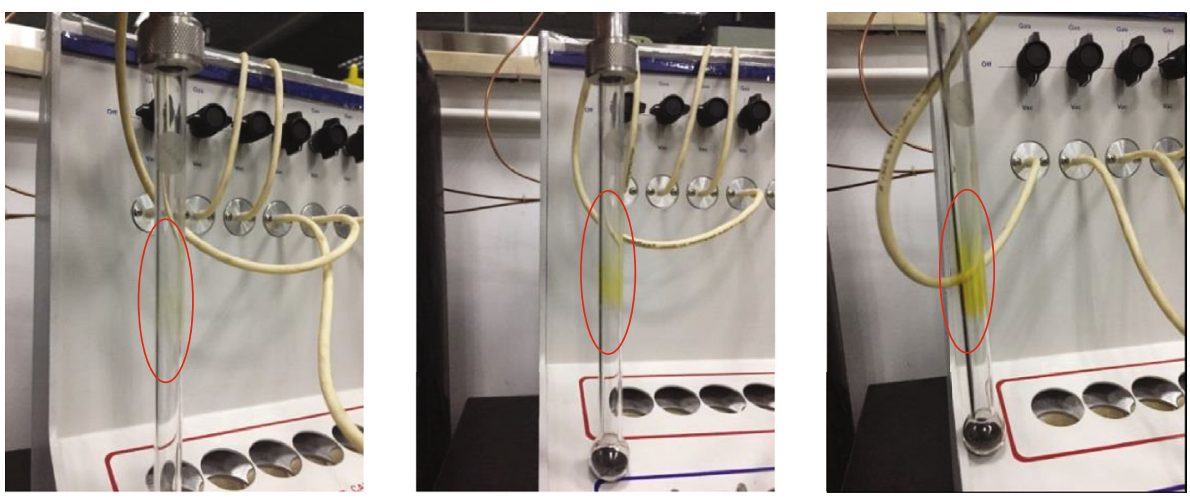

Figure 12: The steam condensate from the volatiles of the coal under various pretreatment temperatures $\left(240^{\circ} \mathrm{C}, 270^{\circ} \mathrm{C}\right.$, and $300^{\circ} \mathrm{C}$, respectively, from the left to right).

contributed by the pores with the aperture below $10 \mathrm{~nm}$ (Figure 4), which is the same with the results from Cai et al. [17]. The cumulative PV presents a quick increase with the pore diameter below $10 \mathrm{~nm}$, while the rise rates under the various pretreatment temperatures are different, and it can be divided into three different types (Figure 4). Type I corresponds to the coal under the pretreatment temperatures of $120^{\circ} \mathrm{C}, 150^{\circ} \mathrm{C}, 180^{\circ} \mathrm{C}$, and $210^{\circ} \mathrm{C}$, which has the quickest rise rate of the cumulative pore volume. When it comes to Type II (with a pretreatment temperature of $240^{\circ} \mathrm{C}$ ), the rise rate of the cumulative pore volume has been decreased. Type III (the pretreatment temperatures are $270^{\circ} \mathrm{C}$ and $300^{\circ} \mathrm{C}$ ) shows the lowest cumulative pore volume rising rate. As for the cumulative $\mathrm{PV}$ rise rates for the greater pore diameters $(>10 \mathrm{~nm})$, it seems the same (Figure 4$)$.

3.3.2. The Change of SSA. The dynamic change of SSA of the coal with the increased pretreatment temperatures presents almost the same with that of the PV (Figure 6). The SSA decreases slowly when the pretreatment temperatures below $150^{\circ} \mathrm{C}$, then there is a sharp decrease of SSA from $180^{\circ} \mathrm{C}$ to $240^{\circ} \mathrm{C}$, and the SSA decreases insignificantly under the high pretreatment temperature of $270^{\circ} \mathrm{C}$ and $300^{\circ} \mathrm{C}$. The initial
SSA is approximately $17.5046 \mathrm{~m}^{2} / \mathrm{g}$ under $120^{\circ} \mathrm{C}$, and it decreases to $2.6955 \mathrm{~m}^{2} / \mathrm{g}$ when the pretreatment temperature reaches $300^{\circ} \mathrm{C}$, with a decreasing amplitude of $83.16 \%$. The decreasing amplitude of the pore volume under $300^{\circ} \mathrm{C}$ is about $65.24 \%$, and the decrease of the SSA is significantly higher than that of the PV. The pores with an aperture less than $10 \mathrm{~nm}$ contribute the dominant SSA of the coal (Figure 7), and dynamic of the cumulative SSA can also be divided into three types with the temperature of $240^{\circ} \mathrm{C}$, the sharp increase of cumulative pore SSA $\left(\leq 210^{\circ} \mathrm{C}\right)$, the slow increase of cumulative pore SSA $\left(\geq 270^{\circ} \mathrm{C}\right)$, and the neutral increase of cumulative pore SSA $\left(240^{\circ} \mathrm{C}\right)$, respectively.

Figure 8 shows that the macropores contribute rarely to the total SSA. The mesopores, especially the mesopores with an aperture below $10 \mathrm{~nm}$, contribute to the total pore SSA. With the increased pretreatment temperatures, there is a significant decrease of the mesopore SSA when the pretreatment temperature reaches $240^{\circ} \mathrm{C}(61.23 \%)$.

3.3.3. The Change of PSD. The mesopores $(<10 \mathrm{~nm})$ are dominant in the DFS coal sample (Figures 9 and 10). The $\mathrm{dV} / \mathrm{dD}$ and $\mathrm{dA} / \mathrm{dD}$ can be divided into three types with the increased pretreatment temperatures. Type I corresponds to the PSD of 

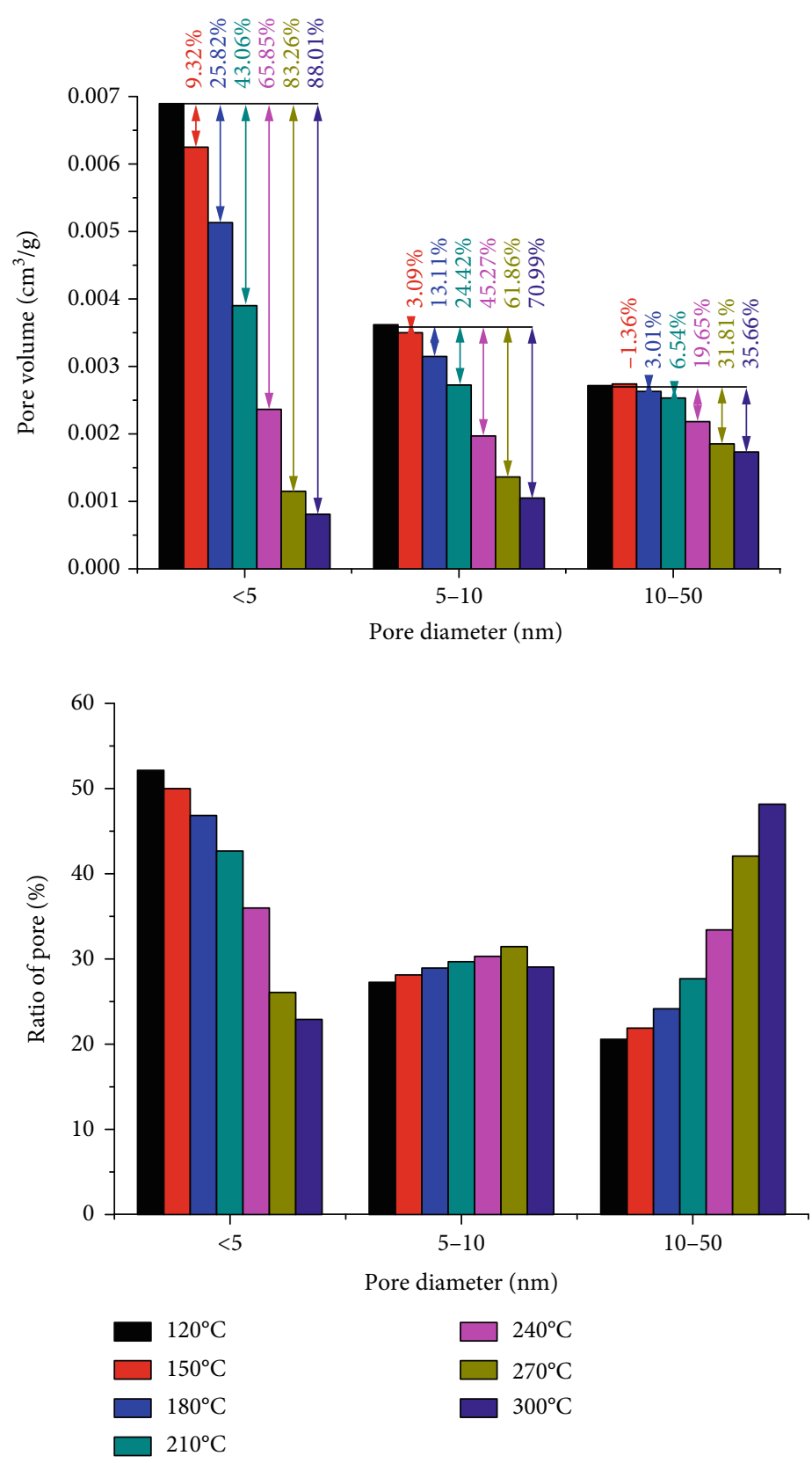

FIGURE 13: The dynamic change of the PV and ratio of the mesopore with different pore ranges under various pretreatment temperatures.

coal with the pretreatment temperature below $240^{\circ} \mathrm{C}$. The $\mathrm{dV} / \mathrm{dD}$ presents a bimodal pattern distribution with a higher left peak of approximately $1.7 \mathrm{~nm}$ and a relatively lower right peak of approximately $3 \mathrm{~nm}$, indicating the smaller pore aperture under the low pretreatment temperatures (Figure 9). The $\mathrm{dA} / \mathrm{dD}$ is almost linear decrease, and the difference contribution of the $\mathrm{dA} / \mathrm{dD}$ from the various pore range decrease, indicating the increase of pore connectivity (Figure 10). When the pretreatment temperature reaches $240^{\circ} \mathrm{C}$ (Type II), the $\mathrm{dV} / \mathrm{dD}$ still presents a bimodal pattern distribution with the right peak of approximately $5 \mathrm{~nm}$, indicating the increased average pore diameter under the higher pretreatment temperature. For Type III, with the pretreatment temperatures of $270^{\circ} \mathrm{C}$ and $300^{\circ} \mathrm{C}$, the bimodal pattern distribution with the left and right peaks is the same with that of Type II, the $\mathrm{dV} / \mathrm{dD}$ and $\mathrm{dA} / \mathrm{dD}$ tend to be balanced, which means the improved pore connectivity.

\subsection{The Influence of Various Pretreatment Temperatures on} Pore Structure. The change of the LP- $\mathrm{N}_{2} \mathrm{~A}$ curves, pore apertures, PV, and SSA under various pretreatment temperatures indicating the pore structure of the coal sample has been changed. The dynamic changes of the pore apertures, PV, and pore SSA of the single coal under various pretreatment temperatures present the three-step-style change, with two cut-off temperature points, $150^{\circ} \mathrm{C}$ and $240^{\circ} \mathrm{C}$, respectively. The mass of the coal sample continuously decreases with the increased pretreatment temperatures (Figure 11). The 

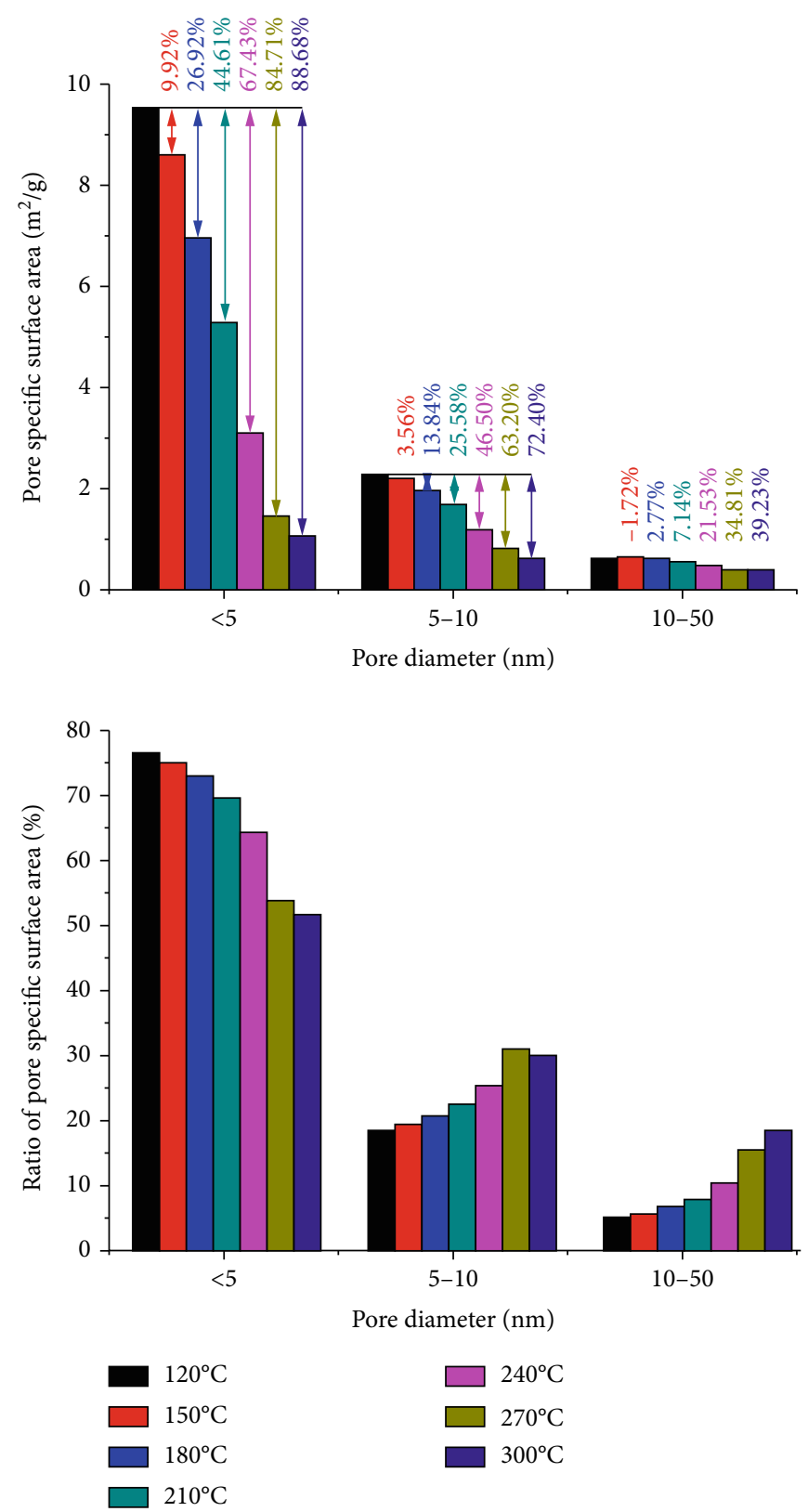

FIGURE 14: The dynamic change of the SSA and ratio of the mesopore with different pore ranges under various pretreatment temperatures.

decrease of the sample mass has a relative to the loss of the water and volatiles in the low-rank coal. The coal samples were first dried under $120^{\circ} \mathrm{C}$, it has exceeded the boiling point of the water, and the water in the macropores and part of the mesopores would evaporate ([33]; [32]; [31]). However, when the test temperatures exceed $100^{\circ} \mathrm{C}$, the interparticle water and the adhesion water would be evaporated continuously [31], but the moisture in the DFS coal sample is low (Table 1); the loss of the water would not be the key factor that leads to the decrease of the sample mass.

Thereby, the decomposition of the volatiles should be another factor that contributes to the decrease of the mass. When the pretreatment temperature reaches $240^{\circ} \mathrm{C}$, there is a certain amount of pyrolysis oil occurrence on the surface of the sample tube (Figure 12). The content of volatiles in the DFS coal is high, which could produce the pyrolysis gas from the coal, and it would condensate to the pyrolysis oil ([20,39]: [40]). The decrease of the volatiles would provide extra space in the coal, resulting in the slow decrease of the PV and pore SSA (Figures 3 and 6). Under the lower pretreatment temperatures $\left(\leq 150^{\circ} \mathrm{C}\right)$, only a small amount of volatile is decomposed. With the decrease of the volatiles, the pore aperture increased. However, with the continuous increase of the pretreatment temperatures, the volatile features massive decomposition, and when the pretreatment temperatures reach $240^{\circ} \mathrm{C}$, it can be found that the gas condensate occurs on the surface of the sample tube. Because of the massive decomposition of the volatiles, the pores in the low-rank coal start to collapse, leading to the sharp decrease of the PV and SSA of the coal, whereas the pore apertures increase. For 


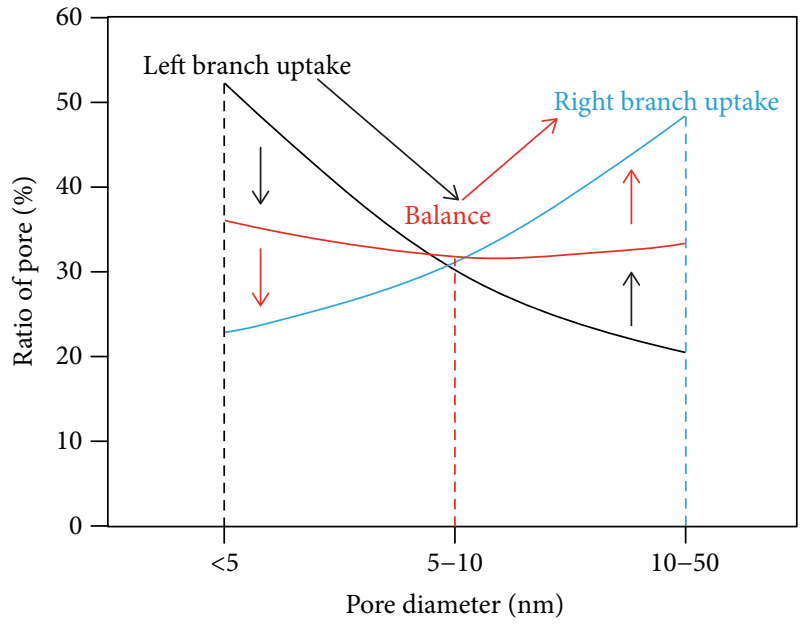

Figure 15: The diagrammatic sketch of the thermal evolution of mesopore structure under various pretreatment temperatures.

the DFS coal sample, there is a certain amount of ash; the ash could maintain the coal skeleton ([41]); then, the decrease of the PV and SSA tends to be decreased under high pretreatment temperatures $\left(\geq 270^{\circ} \mathrm{C}\right)$.

\subsection{Evolution of the Mesopores for DFS Coal}

3.5.1. The PV and SSA of the Mesopores for DFS Coal. The mesopores are dominant in the DFS coal sample, and the $\mathrm{PV}$ and SSA are contributed with the pore below $10 \mathrm{~nm}$. The dynamic change of $\mathrm{dV} / \mathrm{dD}$ and $\mathrm{dA} / \mathrm{dD}$ also shows that the pore aperture below $5 \mathrm{~nm}$ has a significant influence on the PV and pore SSA. Then, the mesopores are divided with the pore aperture of $5 \mathrm{~nm}$ and $10 \mathrm{~nm}$. The PV and pore SSA with the three different pore ranges present a continuous decrease with the increased pretreatment temperatures. The smaller pore apertures, the much more decrease of the PV and SSA. The PV and SSA of the pore aperture below $5 \mathrm{~nm}$ present the most significant decrease, while those for pores with an aperture greater than $10 \mathrm{~nm}$ feature the weakest decrease (Figures 13 and 14). Although the PV and SSA decrease, the ratio of the pore apertures greater than $5 \mathrm{~nm}$ increases, especially that for the pore aperture exceeding $10 \mathrm{~nm}$ (Figures 13 and 14).

3.5.2. The Mesopore Evolution Model of DFS Coal. The pore structure characteristics change significantly with the increased pretreatment temperatures, and the diagrammatic sketch of the evolution of mesopore structure under various pretreatment temperatures is shown in Figure 15. With the low pretreatment temperature of $120^{\circ} \mathrm{C}$, the $\mathrm{PV}$ and SSA are mainly contributed with the pore aperture below $5 \mathrm{~nm}$, and those for the pores with an aperture greater than $10 \mathrm{~nm}$ are least. With the increasing pretreatment temperature, especially when it comes to $240^{\circ} \mathrm{C}$, the pore volumes of $<5 \mathrm{~nm}, 5-10 \mathrm{~nm}$, and $10-50 \mathrm{~nm}$ pores tend to equilibrium. With the continuous increase of the pretreatment temperatures, the content of the pore volumes of $<5 \mathrm{~nm}, 5-10 \mathrm{~nm}$, and $10-50 \mathrm{~nm}$ is contrary with that in the lower pretreatment temperatures, and the pore connectivity of the mesopore is enhanced with the increased pretreatment temperatures.

\section{Conclusions}

(1) The pore structure of the low-rank coal features different characteristics under various pretreatment temperatures, the PV and SSA feature the threestep-style change with the increase of pretreatment temperatures, and the pretreatment temperatures of $150^{\circ} \mathrm{C}$ and $240^{\circ} \mathrm{C}$ can be selected as the cut-off temperature points. The decrease of the PV and SSA under low temperatures $\left(\leq 150^{\circ} \mathrm{C}\right)$ is mainly because of the loss of water and small amount of volatiles in the coal. The massive loss of the volatiles in the coal leads to the rapid decrease of PV and SSA with the temperature ranges from $180^{\circ} \mathrm{C}$ to $240^{\circ} \mathrm{C}$. When the pretreatment temperature exceeds $240^{\circ} \mathrm{C}$, the ash in the coal slows down the decrease of PV and SSA

(2) The mesopore evolution model of the low-rank coal is summarized as the conversion from the left branch uptake to the right branch uptake. The pore system converts from favorable methane adsorption to the seepage of the methane with the increase of pretreatment temperatures

\section{Data Availability}

The author is not allowed to share the data.

\section{Conflicts of Interest}

The author declares that there is no conflict of interest regarding the publication of this paper.

\section{Acknowledgments}

This work was supported by the Natural Science Basic Research Plan in Shaanxi Province of China (Program No. 2019JQ-527), the Shandong Key Laboratory of Depositional Mineralization \& Sedimentary Mineral Open Fund (DMSM20190014), and the Major Project of Education Department of Shaanxi Provincial Government (20JS116).

\section{References}

[1] H. Fu, D. Tang, T. Xu et al., "Characteristics of pore structure and fractal dimension of low-rank coal: A case study of Lower Jurassic Xishanyao coal in the southern Junggar Basin, NW China," Fuel, vol. 193, pp. 254-264, 2017.

[2] K. Jian, X. Fu, Y. Ding, H. Wang, and T. Li, "Characteristics of pores and methane adsorption of low-rank coal in China," Journal of Natural Gas Science and Engineering, vol. 27, pp. 207-218, 2015.

[3] Y. Li, Z. Wang, Z. Pan, X. Niu, Y. Yu, and S. Meng, "Pore structure and its fractal dimensions of transitional shale: A crosssection from east margin of the Ordos Basin, China," Fuel, vol. 241, pp. 417-431, 2019.

[4] J. Yu, A. Tahmasebi, Y. Han, F. Yin, and X. Li, "A review on water in low rank coals: The existence, interaction with coal 
structure and effects on coal utilization," Fuel Processing Technology, vol. 106, pp. 9-20, 2013.

[5] H. Fu, D. Tang, H. Xu et al., "Geological characteristics and CBM exploration potential evaluation: A case study in the middle of the southern Junggar Basin, NW China," Journal of Natural Gas Science and Engineering, vol. 30, pp. 557-570, 2016.

[6] Y. Li, C. Zhang, D. Tang et al., "Coal pore size distributions controlled by the coalification process: An experimental study of coals from the Junggar, Ordos and Qinshui basins in China," Fuel, vol. 206, pp. 352-363, 2017.

[7] H. Xu, D. Z. Tang, D. M. Liu et al., "Study on coalbed methane accumulation characteristics and favorable areas in the Binchang area, southwestern Ordos Basin, China," International Journal of Coal Geology, vol. 95, pp. 1-11, 2012.

[8] Y. Li, J. Yang, Z. Pan, and W. Tong, "Nanoscale pore structure and mechanical property analysis of coal: An insight combining AFM and SEM images," Fuel, vol. 260, article 116352, 2020.

[9] C. Liu, S. Sang, K. Zhang, F. Song, H. Wang, and X. Fan, "Effects of temperature and pressure on pore morphology of different rank coals: implications for $\mathrm{CO}_{2}$ geological storage," Journal of CO2 Utilization, vol. 34, pp. 343-352, 2019.

[10] B. Nie, X. Liu, L. Yang, J. Meng, and X. Li, "Pore structure characterization of different rank coals using gas adsorption and scanning electron microscopy," Fuel, vol. 158, pp. 908917, 2015.

[11] S. Tao, S. Chen, D. Tang, X. Zhao, H. Xu, and S. Li, "Material composition, pore structure and adsorption capacity of lowrank coals around the first coalification jump: A case of eastern Junggar Basin, China," Fuel, vol. 211, pp. 804-815, 2018.

[12] B. Wang, Y. Qin, J. Shen, Q. Zhang, and G. Wang, "Pore structure characteristics of low- and medium-rank coals and their differential adsorption and desorption effects," Journal of Petroleum Science and Engineering, vol. 165, pp. 1-12, 2018.

[13] H. Liu, J. Mou, and Y. Cheng, "Impact of pore structure on gas adsorption and diffusion dynamics for long-flame coal," Journal of Natural Gas Science and Engineering, vol. 22, pp. 203-213, 2015.

[14] R. Sakurovs, L. He, Y. B. Melnichenko et al., "Pore size distribution and accessible pore size distribution in bituminous coals," International Journal of Coal Geology, vol. 100, pp. 51-64, 2012.

[15] Y. S. Nugroho, A. C. McIntosh, and B. M. Gibbs, "Low-temperature oxidation of single and blended coals," Fuel, vol. 79, no. 15, pp. 1951-1961, 2000.

[16] Y. O. Mahidin, H. Usui, and O. Okuma, "The advantages of vacuum-treatment in the thermal upgrading of low-rank coals on the improvement of dewatering and devolatilization," Fuel Processing Technology, vol. 84, no. 1-3, pp. 147-160, 2003.

[17] Y. Cai, D. Liu, Z. Pan, Y. Yao, J. Li, and Y. Qiu, "Pore structure and its impact on $\mathrm{CH} 4$ adsorption capacity and flow capability of bituminous and subbituminous coals from Northeast China," Fuel, vol. 103, pp. 258-268, 2013.

[18] F. Xin, H. Xu, D. Tang et al., "Pore structure evolution of lowrank coal in China," International Journal of Coal Geology, vol. 205, pp. 126-139, 2019.

[19] Y. Li, J. Yang, Z. Pan, S. Meng, K. Wang, and X. Niu, "Unconventional Natural Gas Accumulations in Stacked Deposits: A Discussion of Upper Paleozoic Coal-Bearing Strata in the East Margin of the Ordos Basin, China," Acta Geologica Sinica English Edition, vol. 93, no. 1, pp. 111-129, 2019.
[20] W. Zhang and Z. Xu, "Modeffing Experimental Research of Hydrocarbon Generation from the Thermal Evolution of Low Grade Coal," Natural Gas Industry, vol. 6, pp. 1-7, 1986, In Chinese with an English Abstract.

[21] M. Morimoto, H. Nakagawa, and K. Miura, "Low Rank Coal Upgrading in a Flow of Hot Water," Energy and Fuels, vol. 23, no. 9, pp. 4533-4539, 2009.

[22] Y. Yang, K. Zheng, Z. Li et al., "Experimental study on porefracture evolution law in the thermal damage process of coal," International Journal of Rock Mechanics and Mining Sciences, vol. 116, pp. 13-24, 2019.

[23] J. Zhao, D. Tang, Y. Qin, and H. Xu, "Fractal characterization of pore structure for coal macrolithotypes in the Hancheng area, southeastern Ordos Basin, China," Journal of Petroleum Science and Engineering, vol. 178, pp. 666-677, 2019.

[24] H. Li, S. Shi, J. Lu, Q. Ye, Y. Lu, and X. Zhu, "Pore structure and multifractal analysis of coal subjected to microwave heating," Powder Technology, vol. 346, pp. 97-108, 2019.

[25] R. Sakurovs, C. Lewis, and L. Wibberley, "Effect of heat and moisture on surface titratability and pore size distribution of Victorian brown coals," Fuel, vol. 172, pp. 124-129, 2016.

[26] C. Vogt, T. Wild, C. Bergins, K. Strauß, J. Hulston, and A. L. Chaffee, "Mechanical/thermal dewatering of lignite. Part 4: Physico-chemical properties and pore structure during an acid treatment within the MTE process," Fuel, vol. 93, pp. 433-442, 2012.

[27] A. Arisoy and F. Akgun, "Modelling of spontaneous combustion of coal with moisture content included," Fuel, vol. 73, no. 2, pp. 281-286, 1994.

[28] H. Daigle, A. Johnson, and B. Thomas, "Determining fractal dimension from nuclear magnetic resonance data in rocks with internal magnetic field gradients," Geophysics, vol. 79, no. 6, pp. D425-D431, 2014.

[29] M. le Roux and Q. P. Campbell, "An investigation into an improved method of fine coal dewatering," Minerals Engineering, vol. 16, no. 10, pp. 999-1003, 2003.

[30] Z. Peng, J. Y. Hwang, J. Mouris, R. Hutcheon, and X. Sun, "Microwave Absorption Characteristics of Conventionally Heated Nonstoichiometric Ferrous Oxide," Metallurgical and Materials Transactions A, vol. 42, no. 8, pp. 2259-2263, 2011.

[31] C. A. Pickles, F. Gao, and S. Kelebek, "Microwave drying of a low-rank sub-bituminous coal," Minerals Engineering, vol. 62, pp. 31-42, 2014.

[32] D. L. Luffel and F. K. Guidry, "New Core Analysis Methods for Measuring Reservoir Rock Properties of Devonian Shale," Journal of Petroleum Technology, vol. 44, no. 11, pp. 11841190, 1992.

[33] D. Evans, "The brown-coal/water system: Part 4. Shrinkage on drying," Fuel, vol. 52, no. 3, pp. 186-190, 1973.

[34] C. E. Salmas, A. H. Tsetsekou, K. S. Hatzilyberis, and G. P. Androutsopoulos, "Evolution Lignite Mesopore Structure During Drying. Effect of temperature and heating time," Drying Technology, vol. 19, no. 1, pp. 35-64, 2001.

[35] D. G. Evans, "Effects of colloidal structure on physical measurements on coals," Fuel, vol. 52, no. 2, pp. 155-156, 1973.

[36] S. Deevi and E. Suuberg, "Physical changes accompanying drying of western US lignites," Fuel, vol. 66, no. 4, pp. 454-460, 1987.

[37] J. Wu, J. Wang, J. Liu et al., "Moisture removal mechanism of low-rank coal by hydrothermal dewatering: Physicochemical 
property analysis and DFT calculation," Fuel, vol. 187, pp. 242-249, 2017.

[38] K. S. W. Sing, "Reporting physisorption data for gas/solid systems with special reference to the determination of surface area and porosity (Recommendations 1984)," Pure and Applied Chemistry, vol. 57, no. 4, pp. 603-619, 1985.

[39] T. K. Gale, C. H. Bartholomew, and T. H. Fletcher, "Decreases in the swelling and porosity of bituminous coals during devolatilization at high heating rates," Combustion and Flame, vol. 100, no. 1-2, pp. 94-100, 1995.

[40] J. Xi, J. Liang, X. Sheng, L. Shi, and S. Li, "Characteristics of lump lignite pyrolysis and the influence of temperature on lignite swelling in underground coal gasification," Journal of Analytical and Applied Pyrolysis, vol. 117, pp. 228-235, 2016.

[41] Z. Y. Yin, H. Xu, D. Z. Tang, Y. P. Chen, and T. T. Zhao, "Study on pore structure change during different coal grade pyrolysis," International Journal of Coal Science \& Technology, vol. 47, pp. 74-79, 2019, In Chinese with an English Abstract. 